\title{
Are There Any Beneficial Effects of Spirulina Supplementation for Metabolic Syndrome Components in Postmenopausal Women?
}

\author{
Elena Bobescu ${ }^{1}$ (D) Andreea Bălan ${ }^{1, *}$, Marius Alexandru Moga ${ }^{1}$, Andreea Teodorescu ${ }^{2}$, \\ Maria Mitrică ${ }^{1}$ and Lorena Dima ${ }^{2}$ \\ 1 Department of Medical and Surgical Specialties, Faculty of Medicine, Transilvania University of Brasov, \\ 500019 Brasov, Romania; elena.bobescu@unitbv.ro (E.B.); mogas@unitbv.ro (M.A.M.); \\ maria.mitrica@unitbv.ro (M.M.) \\ 2 Department of Fundamental, Prophylactic and Clinical Sciences, Faculty of Medicine, \\ University Transilvania Brasov, 500019 Brasov, Romania; andreea.teodorescu@unitbv.ro (A.T.); \\ lorena.dima@unitbv.ro (L.D.) \\ * Correspondence: andreea.balan@unitbv.ro; Tel.: +40-769-901-194
}

Received: 17 November 2020; Accepted: 15 December 2020; Published: 17 December 2020

\begin{abstract}
Spirulina is a phytosynthetic filamentous cyanobacterium with microscopic dimensions, which naturally grows in the highly-salted alkaline lakes of Africa, Mexico, America, and Asia. Several bioactive peptides extracted from Spirulina were demonstrated to possess antimicrobial, antiviral, antitumor, immunomodulatory, antiallergic and antihypertensive properties. It has been reported that the consumption of Spirulina could prevent or manage metabolic syndrome components. In women, metabolic disorders are more prevalent during menopause. Postmenopausal women present higher waist circumference, increased blood pressure, hypertriglyceridemia, hyperglycemia, and decreased HDL-cholesterol values, leading to an increased risk of cardiovascular events. Therefore, in order to prevent cardiovascular diseases, it is essential to manage the components of the metabolic syndrome during the postmenopausal period. As recent reports indicated the efficiency of Spirulina supplementation in the management of the metabolic syndrome components, our study aims to review all the clinical trials conducted on this topic. Our main objective is to have a better understanding of whether and how this cyanobacterium could manage the abnormalities included in the metabolic syndrome and if it could be used as a therapeutic approach in postmenopausal women with this condition. We selected relevant articles from PubMed, Google Scholar and CrossRef databases, and a total number of 20 studies met our criteria. All included clinical trials indicated that Spirulina has positive effects in managing metabolic syndrome components. Spirulina is a valuable cyanobacterium that can be used as a food supplement for the management of metabolic syndrome, and it is able to reduce the risk of cardiovascular events. The optimal dose and period of administration remain a debated subject, and future investigations are required. Considering the beneficial effects reported against each component of the metabolic syndrome, Spirulina could also be effective in the postmenopausal period, when this syndrome is the most prevalent, but there is a strong need for human clinical trials in order to sustain this observation.
\end{abstract}

Keywords: Spirulina; menopause; metabolic syndrome; dyslipidemia; insulin resistance; obesity; blood pressure

\section{Introduction}

Spirulina, also known as Arthrospira platensis, is a phytosynthetic filamentous cyanobacterium with microscopic dimensions, which showed intense biomass productivity, with the highest $\mathrm{CO} 2$ fixation 
rate [1]. Spirulina naturally grows in the high-salted alkaline lakes of Africa, Mexico, America and Asia, but at present, it is commercially produced all over the world [2]. There is a large number of Spirulina species, but only three of them were intensively investigated: Spirulina platensis, Spirulina fusiformis and Spirulina maxima [3].

Spirulina has been suggested as an eco-friendly cyanobacterium, which is widely consumed as a nutritional supplement for its multiple beneficial effects on humans and animals' health. This cyanobacterium usually has rapid growth, does not need fertile land for its development [4], and due to its high nutritional value and protein content, it has been proposed for the improvement of meat quality [5]. During the Aztec civilization, more than 400 years ago, Spirulina was consumed as food by the Mayas and Kanembu [3].

Spirulina is a blue-green cyanobacterium that has been used for ancient times due to its extraordinary nutritional profile. It abounds in proteins, which represent almost 60-70\% by dry weight, and also contains all the essential amino acids, high amounts of carotenoids (6.25\%) [6], essential fatty acids (linoleic, gamma-linolenic and palmitic acid), vitamin E, C and selenium [7]. Due to its concentrated nutrition, Spirulina has become in the last years one of such nutraceutical food for managing various health issues [3].

Several bioactive peptides extracted from this cyanobacteria were demonstrated to possess antiantimicrobial, antiviral, antitumor, immunomodulatory, antiallergic and antihypertensive properties (Figure 1) [8]. Furthermore, phycobiliprotein C-phycocyanin and other phenolic phytochemicals from Spirulina exert strong antioxidant and anti-inflammatory effects [9]. According to previous reports, alternative drugs derived from natural products are safer as anti-inflammatory agents than pharmaceutical drugs because they are generating fewer side effects [10].

Spirulina is being used as a therapeutic tool in the management of metabolic syndrome, which is defined as multiple interconnected metabolic abnormalities, including dyslipidemia, glucose intolerance, obesity, hypertension, and prothrombotic state [11]. The worldwide prevalence of this metabolic disorder is about $84 \%$, and it is in a continuous ascent, depending on the region, environment, and population characteristics [12].

Menopause is a physiological period in a woman's life and represents the ovarian function's permanent cessation $[13,14]$. During this period, the prevalence of metabolic syndrome increases. Postmenopausal women present higher waist circumference, increased blood pressure, hypertriglyceridemia, hyperglycemia, and decreased HDL-cholesterol values, leading to an increased risk of cardiovascular events $[15,16]$. Therefore, in order to prevent cardiovascular diseases, it is essential to manage the components of the metabolic syndrome during the postmenopausal period [17,18]. As recent reports indicated the efficiency of Spirulina supplementation in the management of metabolic syndrome components, our study aims to review all the clinical trials conducted on this topic. Moreover, we aim to create a common denominator of them in order to have a better understanding of whether and how this cyanobacterium could improve metabolic abnormalities. Regarding the effects of Spirulina in postmenopausal women with metabolic syndrome, in the literature, there is a lack of clinical trials focused only on this category of subjects. Through our study, we want to gather all the evidence of the effectiveness of Spirulina against the components of the metabolic syndrome in different categories of patients and to pave the way for future studies that would address the effects of this cyanobacterium strictly in postmenopausal women. 


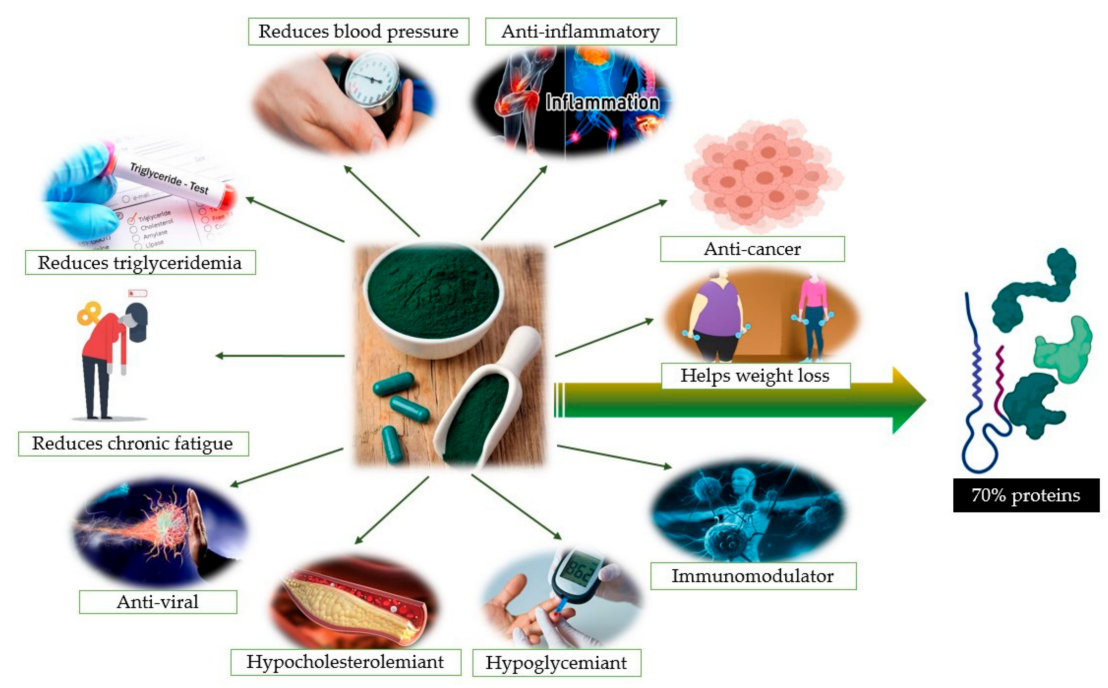

Figure 1. Health benefits of Spirulina supplementation [19].

\section{Metabolic Syndrome and Menopause}

The incidence of metabolic syndrome (obesity, hyperglycemia, dyslipidemia, and hypertension) substantially increases during menopause, in comparison with the menopausal transition. A study including Iranian women has shown that the prevalence of metabolic syndrome was $53.5 \%$ in postmenopausal subjects and 18,3\% during the menopausal transition [20].

Obesity and obesity-related disorders represent a significant public health concern. The real reason for increasing obesity during menopause is not clear for the moment, but many genetic and environmental factors were involved in the pathophysiology of adipose cell accumulation [21]. Some studies reported that sudden estrogen withdrawal might be the most crucial obesity-triggering factor [22]. According to these findings, estrogen deficiency enhances metabolic abnormalities, leading to diabetes mellitus type 2, metabolic syndrome and other cardiovascular events [23].

In the USA, the prevalence of visceral obesity is almost double in comparison with general obesity. Perimenopause is mainly associated with fat redistribution, resulting in the transition from the gynoid to the android fat distribution pattern [24]. The visceral fat is able to secrete adipokines, which are small molecules closely associated with metabolic syndrome. Adipocytes regulate the production of various cytokines, which control the hunger center, the satiety center and modulate the energy repartition in different tissues [25].

Human visceral and subcutaneous adipose tissues express estrogen receptors (ER), such as $\mathrm{ER} \alpha$ and $\mathrm{ER} \beta$ [26]. In brown adipose tissue, ER $\beta$ has not been identified [27]. ER $\alpha$ influences the activity of the adipocytes and the distribution of adipose tissue. Women that lack ER $\alpha$ develops diabetes mellitus type 2 and increased insulin resistance [28]. In conclusion, estrogen is essential for the regulation of adipocytes metabolism and for the pattern of adipose depots. In these conditions, the sudden estrogen decrease induces visceral obesity, metabolic abnormalities and increases the risk for cardiovascular events.

Although the association between central obesity and the alterations of the lipid metabolism in elderly women is well known, the pathophysiological mechanism is not well described yet. Increased visceral depots of adipose tissue usually associate increased free fatty acid levels, insulin resistance, and decreased levels of adiponectin. The consequence consists of increased secretion of apolipoprotein $\mathrm{B}$ (apoB) and increased hepatic lipase activity, leading to hypertriglyceridemia [23].

During menopause, the levels of total cholesterol, triglycerides, and LDL-cholesterol significantly increase, while HDL-cholesterol decreases. The composition of the LDL-cholesterol particles also changes in the postmenopausal period. The preponderance of small and dense LDL-cholesterol molecules, with increased atherogenic potential, is associated with an increased risk of cardiovascular 
diseases [29,30]. Regarding the levels of triglycerides, Poehlman et al. [31] reported that the transition to the postmenopausal period is associated with a $16 \%$ increase in triglyceride levels. Moreover, studies have shown that triglyceride level exponentially increases with the transition to menopause, the highest values being reached in the postmenopausal period [32]. Triglycerides are positively correlated with abdominal fat and insulin resistance [32].

Hypertension is, by far, the most important risk factor for coronary heart diseases (CHD), especially after the age of 63 years [33]. Rising values of the blood pressure during menopause are mainly induced by the increase of vascular stiffness of the great arteries, combined with atherosclerosis, secondary to the lipid metabolism abnormalities [34]. Moreover, during this period, the decline in the estrogen/androgen ratio triggers the production of vasoconstrictive factors, such as endothelin. It significantly decreases the vasorelaxant effects of estrogen on great vessels [35]. In addition, the activation of the renin-angiotensin-aldosterone system (RAA) and the increase of oxidative stress play important roles in the development of hypertension during menopause [35].

Considering that is no animal model of naturally occurring postmenopausal high blood pressure discovered until the present, the elucidation of all the mechanisms involved in hypertension development in menopause dwindled down [36]. In the postmenopausal period, the oxidative stress increases, leading to reduced levels of plasma glutathione peroxidase and increased levels of superoxide dismutase, which triggers the increase of blood pressure. Moreover, in older women, endothelin, a molecule that stimulates oxidative stress by upregulating the subunits of NAD $(P) H$ oxidase, is significantly higher in comparison with younger women.

Many women gain weight or become obese after menopause. This weight gain, associated with the dramatic loss of estrogen levels, usually leads to hypertension and increased incidence of type 2 diabetes mellitus. Previous results have revealed the protective role of estrogen against type 2 diabetes mellitus and metabolic syndrome [37]. Estrogen is able to regulate insulin action by regulating oxidative stress, which contributes to insulin resistance, or by acting directly on insulin-sensitive tissues. It has been reported that ER $\alpha$ exerts positive effects on GLUT4 expression and global insulin action [38].

Obesity and increased visceral adiposity are the main risk factors for type 2 diabetes mellitus in this period [39]. It has been reported that insulin resistance observed in type 2 diabetes mellitus usually occurs in women genetically predisposed when compounded with increased visceral adiposity [40].

All these metabolic changes characteristic for the postmenopausal period should be timely diagnosed and treated to prevent complications. Furthermore, a moderate calorie intake associated with several lifestyle changes (physical exercises, administration of dietary supplements, etc.) could prevent proatherogenic changes and obesity during menopause [41], leading to a great quality of life during this period.

Figure 2 illustrates the mechanisms of the metabolic abnormalities in postmenopausal women.

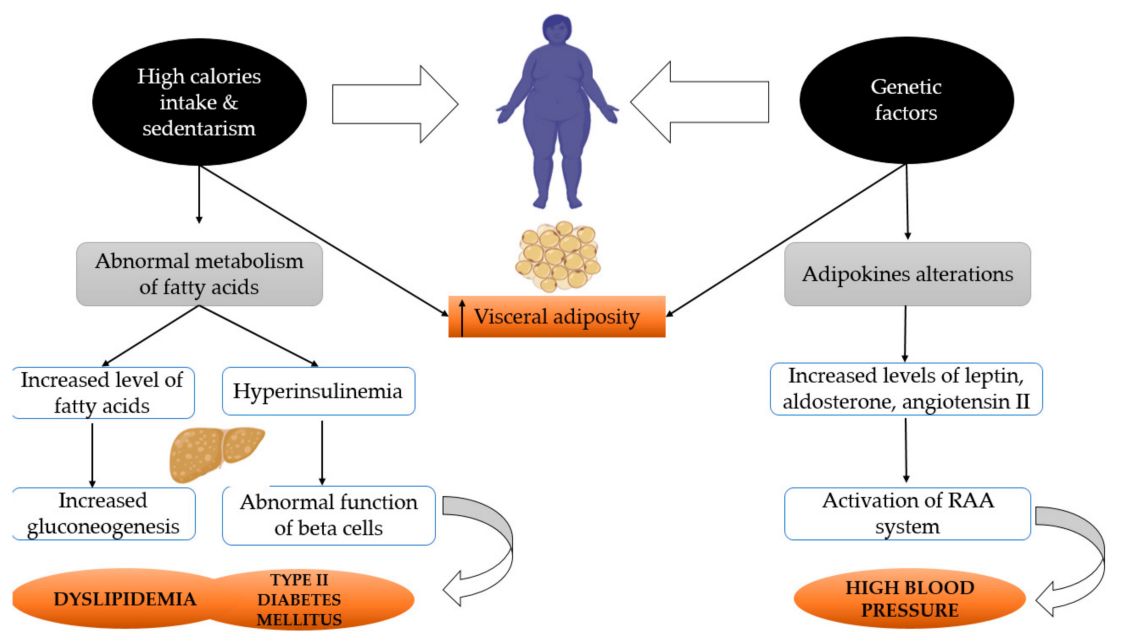

Figure 2. Mechanisms of metabolic abnormalities in postmenopausal women. 


\section{Chemistry and Biochemistry of Spirulina}

The composition of Spirulina mainly consists of carbohydrates, proteins, and lipids [42]. Usually, proteins are associated with biosynthesis and cellular division, while carbohydrates and lipids mainly serve as intracellular reservoirs of energy [43]. Although there are thousands of Spirulina strains available in cultures, significant differences were observed in their main macromolecular composition across the different phyla of this cyanobacterium [44]. A pioneering study conducted in 1961 [45] reported that Spirulina contains 39\% proteins, $23 \%$ carbohydrates and $8 \%$ lipids, on average. More recently, a meta-analysis including 130 studies has shown that the median macromolecular composition of Spirulina consists of $32.2 \%$ proteins, $15 \%$ carbohydrates, $17.3 \%$ lipids and $17.3 \%$ ash [46]. It has been reported that in comparison with eukaryotic microalgal phyla, cyanobacteria possess lower lipid and ash, and higher protein and carbohydrate, as percent dry weight [46]. The composition of Spirulina can be strongly affected by both environmental conditions and phyla [42].

The most well-described alteration induced by inappropriate cultivation conditions consists of nitrogen starvation. This event is leading to lipids accumulation, but the composition of the fatty acids remains unaffected. Nitrogen starvation suspends the synthesis of long-chain fatty acids in Spirulina platensis, and when the quantity of nitrogen is limited, this cyanobacterium stores carbon [47]. Additionally, the phosphorous limitation is leading to increased carbohydrate and lipid content [48].

Regarding the lipid content of Spirulina, it consists of linoleic acid, $\gamma$-linolenic acid, and fatty acids. Lower concentrations of polyunsaturated fatty acids, docosahexaenoic acid, and eicosapentaenoic acid have also been reported [49].

Spirulina has the highest protein and essential amino acid content ever found in one cyanobacterium [50]. Spirulina abounds in phycobiliproteins such as phycoerythrin, phycocyanin and allophycocyanin. Phycoerythrin is a fuchsia pigment, while phycocyanin and allophycoerythrin are bright blue pigments. These pigments are usually used in the food industry, pharmaceutical industry, or cosmetic industry, depending on their purity [42]. Another pigment extracted from Spirulina is phycocyanobilin [51]. It is part of the phycobilins, has a similar structure with biliverdin, and because of these structural similarities, it can be metabolized by biliverdin reductase. Phycocyanobilin is able to exert potent antioxidant and anti-inflammatory properties [52].

Spirulina also contains other constituents, such as vitamins (B vitamin complex) and minerals: selenium, iron, potassium, calcium, zinc, magnesium, etc. [53]. Most cyanobacteria contain pseudo-vitamin B12, an inactive corrinoid, but Spirulina also contains active vitamin B12 [54].

Other compounds described in the composition of Spirulina are carotenoids, a class of pigments that act as provitamin A. From these, zeaxanthin, $\beta$-carotene, and astaxanthin were recently described [49]. Chlorophyll is a green pigment in Spirulina, with antioxidant, anti-inflammatory, and antibacterial properties $[55,56]$.

The chemical structure of Spirulina consists of multicellular cylindrical trichomes. This cyanobacterium is able to create a unique helical shape. Different species of Spirulina can be identified through the length and size of the helix [57]. Overall, these cyanobacteria contain a wide range of essential components for a healthy and balanced diet, and dietary supplementation with Spirulina could have many health benefits by mitigating a wide number of pathologies.

\section{Material and Methods}

This article is a literature review based on Spirulina supplementation effects against the components of the metabolic syndrome. Given the high prevalence of this syndrome in the postmenopausal period, we aimed to investigate whether and how the dietary supplementation with this cyanobacterium could improve the metabolic abnormalities and if it could also be effective in menopausal women. We selected the relevant studies from PubMed, Google Scholar and CrossRef databases, using the following Medical Subject Headings (MeSH) keywords: "Spirulina", "menopause", "metabolic syndrome", "dyslipidemia", "insulin resistance", "obesity", "blood pressure". Two authors separately identified the relevant papers and selected them based on the following inclusion criteria: full-text 
original articles written in English. Only human clinical trials were considered for this review. The exclusion criteria consisted of papers written in languages other than English, abstracts, duplicate papers, and preclinical studies conducted on animals. At final, a number of 20 studies were included in our study, after the exclusion of duplicate papers.

\section{Results}

In the literature, we have not found any clinical trial highlighting the effects of Spirulina consumption in postmenopausal women suffering from metabolic syndrome. At the same time, no studies have been performed on the effects of Spirulina on metabolic syndrome, regardless of the category of included patients. On these conditions, we included in our study all the clinical trials that pointed out the effects of this cyanobacterium on each metabolic abnormality that is part of this syndrome. We found a number of 20 studies that included both women and men with metabolic abnormalities representing components of the metabolic syndrome. The main majority of the studies analyzed elderly subjects, including postmenopausal women. All the studies reported beneficial effects of Spirulina. However, further clinical trials are necessary to support the idea that Spirulina supplementation may aid postmenopausal women to manage the metabolic syndrome.

\subsection{Spirulina Effects on Obesity}

Recent reports suggested that Spirulina consumption may be useful in the management of obesity because of its effects on food absorption and appetite modulation [58]. Although the dietary supplementation with Spirulina seems to be a great opportunity to manage obesity, the scientific evidence in this field is still limited, and a small number of clinical trials were conducted on this topic. In addition, optimal posology is still to be established.

According to Fujimoto et al. [59], the primary mechanism of Spirulina in bodyweight reduction consists of the preventing of liver lipid accumulation, the decrease of oxidative stress and the reduction of the macrophages infiltration into visceral adipose tissue. Moreover, Spirulina is a rich source of essential amino acids, such as phenylalanine, which releases cholecystokinin. This molecule inhibits the appetite center at the level of the central nervous system and works as a bodyweight suppressant [60].

Spirulina also exhibits potent antioxidative effects. Antioxidants are useful in the management of obesity, and they act by various mechanisms: suppress food intake, inhibit the effects of lipase, modulate energy expenditure, inhibit adipocytes differentiation and regulate lipid metabolism [61].

Hernandez-Lepe et al. [62] reported that Spirulina maxima supplementation synergistically improved the effects of physical exercises on body composition in 25 obese and 27 overweight individuals. The body fat percentage was significantly reduced, and the maximal oxygen uptake was improved in subjects that associated physical exercises with Spirulina administration. These findings were more evident in obese than in overweight subjects.

Szulinska et al. [63] included 50 obese subjects in their clinical trial and administered them $2 \mathrm{~g}$ of Spirulina daily for three months. After this period, significant changes were observed in body composition: body mass index (BMI), waist circumference and total body mass decreased in the study group compared to controls, which received a placebo.

Spirulina fusiformis possesses a thin cellular wall, which makes this cyanobacterium an easy to digest nutraceutical food, with supplemental beneficial effects on body weight. Thirty individuals aged between 40 and 60 years were distributed into three groups: the first group received $2 \mathrm{~g}$ of Spirulina fusiformis daily for three months, the second group received $4 \mathrm{~g}$ of Spirulina fusiformis daily for three months, and the third group received placebo. The investigators observed that the reduction of the body weight was substantial in both study groups, in comparison with placebo [64].

Spirulina maxima have also been demonstrated to exert beneficial effects in body weight loss. After three months of daily administration, Miczke et al. [65] reported that regular consumption of this dietary supplement significantly improved BMI and total body weight. The dose of $500 \mathrm{mg}$ of Spirulina administered twice/day for 12 weeks was also beneficial for overweight individuals. 
As Zeinalian et al. [66] reported, $1 \mathrm{~g}$ of Spirulina per day significantly reduced the appetite and decreased BMI and body weight in 64 obese subjects aged between 20 and 50 years. Furthermore, the lipid profile significantly improved.

A clinical trial conducted by Mazokopakis et al. [60] on Cretan subjects with non-alcoholic fatty liver disease reported that the supplementation with $6 \mathrm{~g}$ of Spirulina platensis for six months induced a significant reduction of the body weight, associated with multiple improvements of the metabolic abnormalities. A significant improvement in the health-related quality of life scale was also noticed.

In conclusion, Spirulina is a potent natural agent that can be used in the management of obesity. It induces both bodyweight loss and changes in body composition. Although there is not a wide range of studies conducted in this field, the age of the subjects included so far and the favorable results obtained may support the idea that Spirulina could be an effective treatment for obese or overweight women at menopause. Future studies are needed to optimize doses and the period of administration.

\subsection{Spirulina Effects on Lipid Metabolism}

Increasing evidence reported that doses between 1 and $10 \mathrm{~g}$ of Spirulina for at least 15 days might reduce the levels of atherogenic lipid molecules such as total cholesterol (TC), low-density lipoprotein cholesterol (LDL-C) or very-low-density lipoprotein cholesterol (VLDL-C). In addition, it increases the levels of high-density lipoprotein cholesterol (HDL-C), an antiatherogenic molecule [63,67].

H-b2 is a glycolipid contained by Spirulina, which inhibits pancreatic lipase activity in a dose-dependent manner [68]. Furthermore, phycocyanin has demonstrated its anti-lipase activity. On the other hand, phycocyanin and other bioactive molecules from Spirulina can increase the fecal excretion of cholesterol by decreasing its solubility [69].

Using HepG2 human cells, Ku et al. [70] have demonstrated that Spirulina is able to restore lipid metabolism balance by suppressing the expression of LDL receptor and downregulating the expression of 3-hydroxy-3-methyl-glutaryl-CoA reductase (HMGR). Furthermore, Spirulina inhibits lipid peroxidation and exhibits triglyceride-lowering properties due to the modulation of hepatic lipogenic gene expression and gut cholesterol absorption [70].

A clinical trial conducted by Torres-Duran et al. [71] has shown that the ingestion of $4.5 \mathrm{~g}$ of Spirulina daily for six weeks significantly improved the serum lipids levels. The treatment was administered to 36 individuals aged between 18 and 65 years, which did not modify their lifestyle of diet during the experimental period. After the treatment, LDL-C levels significantly decreased, while HDL-C and TC levels were dependent on triacylglycerol modifications.

Twelve individuals aged between 60 and 75 years were given $7.5 \mathrm{~g}$ of Spirulina daily for 24 weeks [72]. Biochemical assessment for plasma lipid levels has shown that TC, LDL-C and triglycerides levels recorded a significant decrease from only four weeks of the supplementation period. It is important to mention that these effects did not differ between individuals with normal cholesterol levels and hypercholesterolemic patients.

In contrast to the previous results that have shown significant improvements of serum LDL-C, TC and triglycerides levels after the consumption of Spirulina, Zeinalian et al. [66] reported that the intake of this cyanobacterium only partly modifies serum lipids. Sixty-four obese subjects, aged between 20 and 50 years, received $1 \mathrm{~g}$ of Spirulina/day during a period of 12 weeks. After this period, TC significantly reduced in the intervention group, while LDL-C and triglycerides did not suffer significant modifications compared to the control group.

A clinical trial conducted in 2016 on Korean elderly individuals has demonstrated that obesity may influence the hypolipidemic effects of Spirulina. In the non-obese group (BMI $<25 \mathrm{~kg} / \mathrm{m}^{2}$ ), Spirulina supplementation ( $8 \mathrm{~g}$ daily, during a period of 12 weeks) induced a significant decrease in serum levels of TC and LDL-C, while in the obese group (BMI $>25 \mathrm{~kg} / \mathrm{m}^{2}$ ) the results were not so obvious. Moreover, in the first group, the levels of interleukin 2 (IL-2) and antioxidant status levels recorded a significant increase after the treatment. 
In conclusion, Spirulina also exerts beneficial effects on lipid metabolism. We observed that higher doses were administered for a longer period in order to obtain positive effects in comparison with the doses needed to control obesity.

\subsection{Spirulina Effects on Serum Glucose and Insulin Resistance}

Women with increased body mass index $(\mathrm{BMI} \geq 24)$ or with later menopause are more predisposed to develop type 2 diabetes mellitus [73]. This disorder is characterized by metabolic and histological abnormalities due to a defect of insulin secretion or action, associated with oxidative stress [74]. Impaired glucose tolerance is characterized by insufficient insulin response in the peripheral target tissues, and it is a key point in the development of the metabolic syndrome.

Hu et al. [75] have isolated 11 peptides from Spirulina platensis using LC-MS/MS analysis and showed that three of them exhibited antidiabetic activities in vitro. This effect was possible due to their inhibition potential on dipeptidyl peptidase- $4, \alpha$-amylase, and $\alpha$-glucosidase.

Spirulina is rich in proteins and fibers, which induces decreased glucose absorption, associated with increased insulin secretion [76]. It has been demonstrated that Spirulina decreases serum levels of IL-6. This molecule can inhibit insulin-signaling molecules, such as insulin receptor substrate, leading to the suppression of glucose transporter type 4 (GLUT-4) translocation. Through this mechanism, the glucose uptake decreases in adipose depots and skeletal muscles [77].

The hypoglycemic effect of Spirulina has been demonstrated through several clinical trials. Mani et al. [78] observed the effects of Spirulina on non-insulin-dependent diabetes mellitus individuals. After two months of Spirulina supplementation, a significant reduction of glycated serum protein levels and blood sugar levels was observed. Furthermore, the lipid profile was improved, and a serious reduction of LDL-C, VLDL-C and triglycerides was remarked.

Twenty-five patients with type 2 diabetes mellitus were randomized to receive either $2 \mathrm{~g} /$ day of Spirulina or placebo. After two months, fasting blood glucose and HbA1c levels significantly decreased. Moreover, in patients with non-alcoholic fatty liver disease, the administration of Spirulina (6 g daily, for six months) significantly improved the homeostasis model assessment of insulin resistance (HOMA-IR) index [60].

Anitha et al. [79] conducted a study on non-insulin-dependent diabetic volunteers. After 12 weeks of Spirulina administration, a significant decrease in fasting blood glucose and glycosylated hemoglobin levels has been reported. Furthermore, in a group of seventeen HIV-infected subjects, which developed increased insulin-resistance, high doses of Spirulina (19 $\mathrm{g}$ daily for two months) significantly increased insulin sensitivity by $224.7 \%$, in comparison with soybean supplementation [80]. In postmenopausal women, soybean is an alternative and natural treatment used for the management of menopause-related symptoms and pathologies. As we can observe, it also increases insulin sensitivity, but it is less efficient in comparison with Spirulina.

\subsection{Spirulina Effects on Blood Pressure}

Spirulina contains phycocyanin, a blue pigment with antioxidant activity, which is able to decrease the blood pressure values. Phycocyanin has been reported to enhance the expression of endothelial nitric oxide synthase in the aorta under the stimulation of adiponectin [81]. Five major peptides with hypotensive effects have been separated from Spirulina by high-performance liquid chromatography. Oral administration of Ile-Ala-Glu, Ala-Glu-Leu, Val-Ala-Phe, Ile-Ala-Glu, Ile-Ala-Pro-Gly (200 mg/kg) in hypertensive rats resulted in significant antihypertensive effects. The molecular mechanism of these peptides in hypertension includes the inhibition of angiotensin I-converting enzyme [82]. Furthermore, the peptides derived from Spirulina lower blood pressure values by inhibiting the RAA system [81].

Martinez-Samano et al. [83] performed a clinical trial, which included 16 patients with systemic arterial hypertension. Eight of them received Spirulina maxima and angiotensin-converting enzyme inhibitors, while the other eight received only angiotensin-converting enzyme inhibitors. After three months of daily administration, the researchers observed that systolic blood pressure significantly 
decreased in the group that received both medical treatment and Spirulina. Diastolic blood pressure did not register statistically significant modifications in the group that received both Spirulina and angiotensin-converting enzyme inhibitor.

According to the reports of Torres-Duran et al. [71], daily administration of $4.5 \mathrm{~g}$ of Spirulina for six weeks to overweight subjects may improve both systolic and diastolic values of the blood pressure. Moreover, the dietary supplementation with this product in patients with type 2 diabetes mellitus induced a significant reduction of the blood pressure. According to Lee et al. [84], the administration of $8 \mathrm{~g}$ of Spirulina daily for three months recorded excellent results in type 2 diabetes mellitus subjects.

Mickze et al. [65] also conducted a study to demonstrate the beneficial effects of Spirulina in overweight hypertensive patients. After three months of daily administration ( $2 \mathrm{~g}$ of Spirulina), the patients showed a significant reduction in systolic blood pressure.

These records demonstrate that regular consumption of Spirulina may improve blood pressure, especially in overweight patients. However, the posology and the optimal period of administration are still controversial. For this reason, further studies with longer duration and larger sample sizes are necessary to be conducted.

Table 1 synthesizes all the clinical studies regarding the effects of Spirulina on the components of metabolic syndrome, included in our systematic review. 
Table 1. Studies regarding the effects of Spirulina on the components of metabolic syndrome.

\begin{tabular}{|c|c|c|c|c|c|}
\hline Author, Year & Type of Study & Spirulina Effect & Participants & Posology & Results \\
\hline $\begin{array}{l}\text { Ramamoorthy et al. } \\
1996 \text { [64] }\end{array}$ & $\begin{array}{l}\text { Double-blind } \\
\text { placebo-controlled }\end{array}$ & $\begin{array}{ll}\text { - } & \text { Bodyweight reduction } \\
\text { - } & \text { Hypocholesterolemiant effect }\end{array}$ & $\begin{array}{l}30 \text { overweight patients aged } \\
\text { between } 40 \text { and } 60 \text { years, with } \\
\text { high blood cholesterol levels }\end{array}$ & $\begin{array}{l}\text { Group A-2 } \mathrm{g} \text { of Spirulina daily }-3 \text { months } \\
\text { Group B-4 } \mathrm{g} \text { of Spirulina daily }-3 \text { months } \\
\text { Group C-placebo }\end{array}$ & $\begin{array}{l}\text { Mean initial weights } \\
\text { significantly decreased in group } \\
\text { A and B compared to group C } \\
\text { Total cholesterol levels } \\
\text { significantly decreased in } \\
\text { group B } \\
\text { - Serum triglyceride, LDL, VLDL } \\
\text { levels significantly decreased in } \\
\text { group A and B in comparison } \\
\text { with group C } \\
\text { - HDL significantly increased in } \\
\text { group A and B in comparison } \\
\text { with group C }\end{array}$ \\
\hline Kim et al. 2003 [72] & $\begin{array}{l}\text { Randomized clinical } \\
\text { trial }\end{array}$ & $\begin{array}{l}\text { - } \quad \text { Improves lipid metabolism } \\
\text { Improves antioxidant } \\
\text { capacity and } \\
\text { immune function }\end{array}$ & $\begin{array}{l}6 \text { males and } 6 \text { females aged } \\
\text { between } 60 \text { and } 75 \text { years }\end{array}$ & $7.5 \mathrm{~g}$ of Spirulina daily -6 months & $\begin{array}{l}\text { Serum levels of triglycerides, } \\
\text { total cholesterol and } \\
\text { LDL-cholesterol } \\
\text { significantly decreased } \\
\text { Immune function and } \\
\text { antioxidant capacity } \\
\text { significantly improved } \\
\text { No modification was recorded } \\
\text { for anthropometric parameters }\end{array}$ \\
\hline Samuels et al. 2004 [85] & $\begin{array}{l}\text { Double-blind } \\
\text { placebo-controlled }\end{array}$ & - $\quad$ Hypocholesterolemiant effect & $\begin{array}{c}23 \text { patients aged between } 2 \text { and } \\
13 \text { years with nephrotic } \\
\text { syndrome and secondary } \\
\text { hyperlipidemia }\end{array}$ & $\begin{array}{l}\text { Group } 1-\text { medication }-2 \text { months } \\
\text { Group } 2-\text { medication and } 1 \mathrm{~g} \text { of Spirulina } \\
\text { daily }-2 \text { months }\end{array}$ & $\begin{array}{l}\text { Anthropometric parameters } \\
\text { were normal compared with } \\
\text { healthy individuals } \\
\text { Triglycerides, total cholesterol } \\
\text { and LDL-cholesterol levels } \\
\text { significantly decreased in } \\
\text { group 2 } \\
\text { LDL-C:HDL-C ratio decreased } \\
\text { more significant in group 2 }\end{array}$ \\
\hline
\end{tabular}


Table 1. Cont

\begin{tabular}{|c|c|c|c|c|c|}
\hline Author, Year & Type of Study & Spirulina Effect & Participants & Posology & Results \\
\hline Parikh et al. 2004 [76] & $\begin{array}{l}\text { Double-blind } \\
\text { placebo-controlled }\end{array}$ & $\begin{array}{ll}\text { - } & \text { Hypoglycemia effects } \\
\text { - } & \text { Hypocholesterolemiant effects }\end{array}$ & $\begin{array}{c}25 \text { patients with type } 2 \text { diabetes } \\
\text { mellitus }\end{array}$ & $\begin{array}{l}\text { Group } 1-2 \mathrm{~g} \text { of Spirulina daily }-2 \text { months } \\
\text { Group } 2-\text { placebo }\end{array}$ & $\begin{array}{l}\text { Fasting blood glucose and } \\
\text { postprandial blood glucose } \\
\text { levels significantly decreased } \\
\text { HbA1c levels showed a } \\
\text { significant reduction } \\
\text { Total cholesterol, } \\
\text { LDL-cholesterol decreased, and } \\
\text { HDL-cholesterol increased in } \\
\text { group 1 } \\
\text { apo B decreased, and apo } \\
\text { A1 increased }\end{array}$ \\
\hline $\begin{array}{l}\text { Torres-Duran et al. } 2007 \\
\text { [71] }\end{array}$ & Prospective study & $\begin{array}{ll}\text { - } & \text { Antihyperlipidemic effects } \\
\text { - } & \text { Antihypertensive effects }\end{array}$ & $\begin{array}{l}16 \text { men and } 20 \text { women aged } \\
\text { between } 18 \text { and } 65 \text { years }\end{array}$ & $\begin{array}{l}\text { All the participants received } 4.5 \mathrm{~g} \text { of } \\
\text { Spirulina daily for } 6 \text { weeks }\end{array}$ & $\begin{array}{l}\text { Significant differences were } \\
\text { registered in triacylglycerols, } \\
\text { total cholesterol and } \\
\text { HDL-cholesterol levels } \\
\text { Lower values of systolic and } \\
\text { diastolic blood pressured were } \\
\text { observed after the treatment }\end{array}$ \\
\hline Lee et al. 2008 [84] & $\begin{array}{c}\text { Double-blind } \\
\text { placebo-controlled }\end{array}$ & $\begin{array}{ll}\text { - } & \text { Bodyweight reduction } \\
\text { - } & \text { Antihyperlipidemic effects } \\
\text { - } & \text { Antihypertensive effects }\end{array}$ & $\begin{array}{l}15 \text { males and } 16 \text { females aged } \\
\text { between } 30 \text { and } 70 \text { years, with } \\
\text { type } 2 \text { diabetes mellitus }\end{array}$ & $\begin{array}{l}\text { Study group- } 8 \mathrm{~g} \text { of Spirulina } \\
\text { daily-3 months } \\
\text { Control group-placebo }\end{array}$ & $\begin{array}{l}\text { - Anthropometric parameters } \\
\text { were not significantly changed } \\
\text { for both Spirulina and } \\
\text { control groups. } \\
\text { Plasma triglycerides and } \\
\text { diastolic blood pressure } \\
\text { significantly decreased in the } \\
\text { study group in comparison } \\
\text { with controls, } \\
\text { - Plasma adiponectin increased } \\
\text { - The individuals with higher } \\
\text { initial triglyceride serum level } \\
\text { showed a more significant } \\
\text { reduction in weight, abdominal } \\
\text { fat thickness, waist-to-hip ratio, } \\
\text { triglyceride levels, atherogenic } \\
\text { index, and diastolic } \\
\text { blood pressure }\end{array}$ \\
\hline
\end{tabular}


Table 1. Cont.

\begin{tabular}{|c|c|c|c|c|c|}
\hline Author, Year & Type of Study & Spirulina Effect & Participants & Posology & Results \\
\hline Kaur et al. 2008 [86] & $\begin{array}{c}\text { Double-blind } \\
\text { placebo-controlled }\end{array}$ & $\begin{array}{ll}\text { - } & \text { Hypoglycemic effects } \\
\text { - } & \text { Antihyperlipidemic effects }\end{array}$ & $\begin{array}{c}60 \text { males aged between } 40 \text { and } \\
60 \text { years, with type } 2 \text { diabetes } \\
\text { mellitus }\end{array}$ & $\begin{array}{l}\text { Group E1-1 g of Spirulina daily-2 } \\
\text { months } \\
\text { Group E2-2 } \mathrm{g} \text { of Spirulina daily }-2 \\
\text { monthsGroup C-placebo }\end{array}$ & $\begin{array}{l}\text { The mean fasting and } \\
\text { postprandial blood glucose } \\
\text { level significantly decreased in } \\
\text { group E1 and E2 } \\
\text { Total cholesterol, triglycerides, } \\
\text { LDL-cholesterol and } \\
\text { VLDL-cholesterol levels } \\
\text { significantly decreased in } \\
\text { E groups. }\end{array}$ \\
\hline Park et al. 2008 [77] & $\begin{array}{c}\text { Randomized } \\
\text { double-blind, } \\
\text { placebo-controlled } \\
\text { study }\end{array}$ & $\begin{array}{ll}\text { - } & \text { Antihyperlipidemic effects } \\
\text { - } & \text { Improves immune status } \\
\text { - } & \text { Antioxidant effects }\end{array}$ & $\begin{array}{c}78 \text { subjects aged between } 60 \\
\text { and } 87 \text { years }\end{array}$ & $\begin{array}{l}\text { Study group }-8 \mathrm{~g} \text { of Spirulina daily }-16 \\
\text { weeks } \\
\text { Control group }- \text { placebo }\end{array}$ & 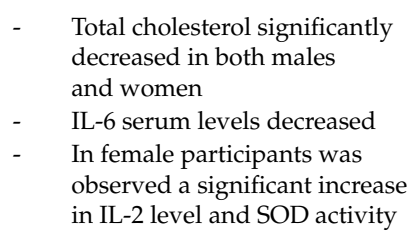 \\
\hline Anitha et al. 2010 [79] & $\begin{array}{c}\text { Randomized } \\
\text { double-blind, } \\
\text { placebo-controlled } \\
\text { study }\end{array}$ & $\begin{array}{ll}\text { - } & \text { Hypoglycemic effects } \\
\text { - } & \text { Antihyperlipidemic effects }\end{array}$ & $\begin{array}{l}160 \text { male volunteers, } \\
\text { non-insulin-dependent } \\
\text { diabetics }\end{array}$ & $\begin{array}{l}\text { Group 1-placebo } \\
\text { Group 2-dietary regimen }+1 \mathrm{~g} \\
\text { Spirulina-12 weeks } \\
\text { Group 3-diet and drugs }+1 \mathrm{~g} \\
\text { Spirulina-12 weeks } \\
\text { Group 4-diet, drugs, and insulin }+1 \mathrm{~g} \\
\text { Spirulina }-12 \text { weeks }\end{array}$ & $\begin{array}{l}\text { The levels of fasting blood } \\
\text { glucose and glycosylated } \\
\text { hemoglobin } \\
\text { significantly decreased } \\
\text { - } \quad \text { HDL-cholesterol increased } \\
\text { - } \quad \begin{array}{l}\text { Lipid profile } \\
\text { significantly improved }\end{array}\end{array}$ \\
\hline $\begin{array}{c}\text { Azabji-Kenfack et al. } \\
2011 \text { [80] }\end{array}$ & $\begin{array}{l}\text { Randomized } \\
\text { double-blind, } \\
\text { placebo-controlled } \\
\text { study }\end{array}$ & - $\quad$ Improves insulin sensitivity & $\begin{array}{l}33 \text { insulin-resistant } \\
\text { HIV-infected patients }\end{array}$ & $\begin{array}{l}17 \text { subjects received } 19 \mathrm{~g} \text { of Spirulina daily } \\
\text { for } 2 \text { months } \\
16 \text { subjects received soybean }\end{array}$ & $\begin{array}{l}100 \% \text { vs. } 69 \% \text { of subjects on } \\
\text { Spirulina versus soybean, } \\
\text { respectively, improved their } \\
\text { insulin sensitivity }\end{array}$ \\
\hline $\begin{array}{c}\text { Mazokopakis et al. } 2014 \\
\text { [60] }\end{array}$ & Prospective study & $\begin{array}{ll}\text { - } & \text { Hypocholesterolemiant effects } \\
\text { - } & \text { Bodyweight loss }\end{array}$ & $\begin{array}{c}13 \text { men and } 2 \text { women aged } \\
\text { between } 29 \text { and } 62 \text { years, with } \\
\text { non-alcoholic fatty liver disease }\end{array}$ & $6 \mathrm{~g}$ of Spirulina daily for 6 months & 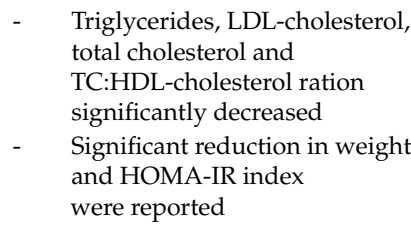 \\
\hline
\end{tabular}


Table 1. Cont.

\begin{tabular}{|c|c|c|c|c|c|}
\hline Author, Year & Type of Study & Spirulina Effect & Participants & Posology & Results \\
\hline Ismail et al. 2014 [87] & $\begin{array}{c}\text { Randomized } \\
\text { double-blind, } \\
\text { placebo-controlled } \\
\text { study }\end{array}$ & $\begin{array}{ll}\text { - } & \text { Improves lipid metabolism } \\
\text { - } & \text { Antioxidant effects }\end{array}$ & $\begin{array}{l}30 \text { subjects with chronic } \\
\text { obstructive pulmonary disease } \\
\text { and } 20 \text { healthy controls }\end{array}$ & $\begin{array}{l}\text { Group } 1-1 \mathrm{~g} \text { of Spirulina daily for } 60 \text { days } \\
\text { Group } 2-2 \mathrm{~g} \text { of Spirulina daily for } 60 \text { days } \\
\text { Group } 3-\text { placebo }\end{array}$ & $\begin{array}{ll}\text { - } & \text { Serum contents of total } \\
\text { cholesterol, lipid } \\
\text { hydroperoxide, and } \\
\text { malondialdehyde were } \\
\text { significantly decreased }\end{array}$ \\
\hline $\begin{array}{l}\text { Ngo-Matip et al. } 2014 \\
\text { [88] }\end{array}$ & $\begin{array}{l}\text { Prospective, } \\
\text { single-blind, } \\
\text { randomized study }\end{array}$ & - Improves lipid metabolism & $\begin{array}{l}169 \text { HIV-antiretroviral naïve } \\
\text { subjects, with metabolic } \\
\text { alterations }\end{array}$ & $\begin{array}{l}\text { Group 1-Local diet }+ \text { Spirulina } \\
\text { supplementation-12 months } \\
\text { Group 2-Local diet only }\end{array}$ & $\begin{array}{l}\text { In group } 1 \text { was observed a } \\
\text { significant increase in } \\
\text { HDL-cholesterol and a } \\
\text { significant decrease in total } \\
\text { cholesterol, LDL-cholesterol } \\
\text { and triglyceride levels }\end{array}$ \\
\hline Mani et al. 2015 & Prospective study & $\begin{array}{ll}\text { - } & \text { Hypoglycemiant effects } \\
\text { - } & \text { Antihyperlipidemic effects }\end{array}$ & $\begin{array}{l}15 \text { non-insulin-dependent } \\
\text { diabetes mellitus subjects }\end{array}$ & $2 \mathrm{~g}$ of Spirulina-2 months & $\begin{array}{l}\text { Blood sugar levels and glycated } \\
\text { serum protein levels } \\
\text { significantly decreased } \\
\text { Total cholesterol, free fatty } \\
\text { acids, triglycerides, } \\
\text { LDL-cholesterol, } \\
\text { VLDL-cholesterol, } \\
\text { HDL-C/LDL-C } \\
\text { significantly degreased }\end{array}$ \\
\hline Park et al. 2016 [89] & $\begin{array}{c}\text { Randomized } \\
\text { double-blind, } \\
\text { placebo-controlled } \\
\text { study }\end{array}$ & $\begin{array}{ll}\text { - } & \text { Antihyperlipidemic effects } \\
\text { - } & \text { Antioxidant effects } \\
\text { - } & \text { Enhances the immune system }\end{array}$ & 78 patients aged $60-87$ years & $\begin{array}{l}\text { Group } 1-8 \mathrm{~g} \text { of Spirulina daily-12 weeks } \\
\text { Group } 2-\text { placebo }\end{array}$ & $\begin{array}{ll}\text { - } & \text { Serum levels of LDL-cholesterol } \\
\text { and triglycerides } \\
\text { significantly decreased } \\
\text { - } & \text { IL-2 increased } \\
\text { - } & \text { Total antioxidant status level } \\
\text { significantly increased }\end{array}$ \\
\hline
\end{tabular}


Table 1. Cont.

\begin{tabular}{|c|c|c|c|c|c|}
\hline Author, Year & Type of Study & Spirulina Effect & Participants & Posology & Results \\
\hline Micze et al. 2016 [65] & $\begin{array}{l}\text { Randomized } \\
\text { double-blind, } \\
\text { placebo-controlled } \\
\text { study }\end{array}$ & $\begin{array}{ll}- & \text { Bodyweight loss } \\
\text { - } & \text { Hypotensive effects }\end{array}$ & $\begin{array}{l}40 \text { hypertensive individuals, } \\
\text { lacking evidence of } \\
\text { cardiovascular disease }\end{array}$ & $\begin{array}{l}\text { Group } 1-2 \mathrm{~g} \text { of Spirulina daily }-3 \text { months } \\
\text { Group } 2-\text { placebo }\end{array}$ & $\begin{array}{l}\text { - The subjects from group } 1 \\
\text { showed significant reductions } \\
\text { in BMI and weight } \\
\text { - Systolic blood pressure and } \\
\text { stiffness index significantly } \\
\text { decreased in the study group }\end{array}$ \\
\hline Zeinalian et al. 2017 [66] & $\begin{array}{l}\text { Randomized } \\
\text { double-blind, } \\
\text { placebo-controlled } \\
\text { study }\end{array}$ & $\begin{array}{l}\text { - Improves lipid metabolism } \\
\text { - } \quad \text { Decreases appetite and } \\
\text { body weight }\end{array}$ & $\begin{array}{l}64 \text { obese subjects aged between } \\
20 \text { and } 50 \text { years }\end{array}$ & $\begin{array}{l}29 \text { subjects received } 1 \mathrm{~g} \text { of Spirulina } \\
\text { daily-12 weeks } \\
27 \text { subjects—control group-received } \\
\text { placebo }\end{array}$ & $\begin{array}{l}\text { Bodyweight and body mass } \\
\text { index significantly decreased in } \\
\text { Spirulina-treated group; } \\
\text { appetite decreased in the } \\
\text { study group } \\
\text { - Serum VEGF, LDL-cholesterol } \\
\text { and triglycerides levels did not } \\
\text { change significantly } \\
\text { after intervention } \\
\text { - HDL-cholesterol significantly } \\
\text { increased in both groups }\end{array}$ \\
\hline $\begin{array}{l}\text { Hernandez-Lepe et al. } \\
2018 \text { [62] }\end{array}$ & $\begin{array}{l}\text { Randomized } \\
\text { double-blind, crossover } \\
\text { controlled trial }\end{array}$ & $\begin{array}{l}\text { Improves the effects of } \\
\text { physical exercises on body } \\
\text { composition and } \\
\text { cardiorespiratory fitness } \\
\text { parameters in obese and } \\
\text { overweight patients }\end{array}$ & $\begin{array}{l}27 \text { overweight and } \\
25 \text { obese males }\end{array}$ & $\begin{array}{l}\text { Group } 1 \text {-physical exercise program twice } \\
\text { weekly }+4.5 \mathrm{~g} \text { of Spirulina }-6 \text { weeks } \\
\text { Group 2-physical exercise program twice } \\
\text { weekly } \\
\text { Group 3-no physical exercise program + } \\
4.5 \mathrm{~g} \text { of Spirulina } 6 \text { weeks } \\
\text { Group } 4-\text { control group }\end{array}$ & $\begin{array}{l}\text { Spirulina improved the maximal } \\
\text { oxygen uptake and decreased } \\
\text { the body fat percentage } \\
\text { The time to reach fatigue and } \\
\text { the onset of blood lactate } \\
\text { accumulation were improved in } \\
\text { group } 1 \text { and group } 3\end{array}$ \\
\hline $\begin{array}{l}\text { Martinez-Samano et al. } \\
\text { 2018 [83] }\end{array}$ & $\begin{array}{l}\text { Prospective, } \\
\text { randomized, parallel } \\
\text { pilot study }\end{array}$ & $\begin{array}{ll}\text { - } & \text { Antihypertensive effects } \\
\text { - } & \text { Antioxidant effects }\end{array}$ & $\begin{array}{l}16 \text { patients with systemic } \\
\text { arterial hypertension } \\
\text { undergoing treatment with } \\
\text { angiotensin-converting enzyme }\end{array}$ & $\begin{array}{l}\text { Group } 1 \text {-angiotensin-converting enzyme } \\
+4.5 \mathrm{~g} \text { of Spirulina for } 12 \text { weeks } \\
\text { Group } 2 \text {-placebo }+ \\
\text { angiotensin-converting enzyme }\end{array}$ & $\begin{array}{ll}\text { - } & \text { Systolic blood pressure } \\
\text { significantly decreased } \\
\text { sVCAM-1, E-selectin and } \\
\text { endothelin-1 levels } \\
\text { significantly decreased } \\
\text { - } & \text { Glutathione peroxidase activity } \\
\text { and oxidized glutathione } \\
\text { levels decreased }\end{array}$ \\
\hline $\begin{array}{l}\text { Pancholi et al. } 2019 \\
\text { [90] }\end{array}$ & Prospective study & - $\quad$ Helps body weight loss & $\begin{array}{l}100 \text { obese patients aged } \\
\text { between } 18 \text { and } 70 \text { years } \\
\text { (50 women and } 50 \text { males) }\end{array}$ & $\begin{array}{l}\text { Group 1-non-Spirulina supplementation } \\
\text { Group } 2-5 \mathrm{~g} \text { of Spirulina daily-45 days }\end{array}$ & $\begin{array}{l}\text { - The subjects from group } 2 \text { lost } 3 \\
\mathrm{~kg} \text { weight and improved } \\
\text { sleeping quality }\end{array}$ \\
\hline
\end{tabular}




\section{Side Effects of Spirulina Administration}

Very few reports regarding possible side effects of Spirulina consumption were made. However, in some cases, it may cause allergic reactions, headaches, sweating, or sleep disorders [91]. People with known allergies to various seafood or seaweeds should avoid the administration of Spirulina [92].

Lee et al. [93] reported that immunostimulatory dietary supplements, such as Spirulina, may exacerbate preexisting autoimmune disease. A patient that ingested Spirulina platensis presented a severe episode of dermatomyositis, while two patients that consumed Echinacea and Spirulina platensis developed pemphigus vulgaris only several days after the ingestion. The real mechanism of this phenomenon is still controversial, but the increased production of TNF- $\alpha$ may play a significant role.

Another side effect of Spirulina was reported by Mazokopakis et al. [94], which described the first case of acute rhabdomyolysis after the ingestion. A 17-year-old male developed anaphylaxis the first time he ingested a Spirulina tablet, according to Le et al. [95]. The diagnosis of Spirulina allergy can be simply established by using a skin prick test with dilutions of Spirulina platensis [95].

The consumption of this cyanobacterium can induce abdominal pain, nausea, or flatulence when it is consumed for the first time. If Spirulina is infected with various contaminants from the water, toxins, heavy metals or pollutants, it also gives rise to severe gastric perturbances. The safety of this product for pregnant or breastfeeding women is not well established, so it is recommended to be avoided during these periods.

\section{Conclusions}

Spirulina either grows in marine waters or can be cultured in special conditions and environments, and it has been proven that it possesses many therapeutic effects, including hypoglycemic, anti-obesity, antihyperlipidemic, and hypotensive activities. The administration of Spirulina has proved to be very efficient for the regulation of these metabolic abnormalities, which together constitute metabolic syndrome, one of the most prevalent pathologies in the elderly population, especially in the postmenopausal period. Despite there is a lack of studies focused on the effects of Spirulina in postmenopausal women with metabolic syndrome, we hope that our study paves the way for the researchers in this direction. In our opinion, given the beneficial effects of Spirulina on each component of the metabolic syndrome, the cumulative effect could fully target postmenopausal metabolic syndrome.

Although multiple clinical trials were conducted on the activity of Spirulina on metabolic abnormalities, the optimal dose and period of administration are still controversial and need a consensus. According to previous data, a minimal dose of $2 \mathrm{~g}$ of Spirulina, administered daily for a minimum of 2 months, recorded favorable results. High doses of Spirulina (18 or $19 \mathrm{~g} /$ day) administered for an extended period were also reported to have beneficial effects. According to the Food and Drug Administration, a recommended dosage for adults is usually in the range of 3-10 g day [96]. Multiple integrations with Spirulina and other nutraceuticals in menopausal women could influence the optimal dose, but there is no study conducted on this topic until now. Spirulina is generally recognized as safe for human consumption, but patients known with preexisting autoimmune diseases should avoid the ingestion of this cyanobacterium.

In conclusion, the seemingly conflicting results of the previous studies and the lack of studies focused on the effects of Spirulina on metabolic syndrome in both postmenopausal women and other categories of patients highlight the need for further comprehensive research in this field. In our opinion, based on the results obtained until now, the dietary supplementation of postmenopausal women with Spirulina could be a very attractive and efficient way to solve the metabolic abnormalities secondary to the sudden estrogen withdrawal.

Author Contributions: Conceptualization, L.D; methodology, M.A.M.; investigation, A.T.; resources, M.M.; writing-original draft preparation, A.B.; supervision, E.B., L.D. All authors have read and agreed to the published version of the manuscript. 
Funding: This research received no external funding.

Conflicts of Interest: The authors declare no conflict of interest.

\section{Abbreviations}

$\begin{array}{ll}\text { BMI } & \text { Body mass index } \\ \text { CHD } & \text { Coronary heart disease } \\ \text { ER } & \text { Estrogen receptor } \\ \text { GLUT-4 } & \text { Glucose transporter type } 4 \\ \text { HDL-C } & \text { High-density lipoprotein cholesterol } \\ \text { HMGR } & \text { 3-hydroxy-3-methyl-glutaryl-CoA reductase } \\ \text { HOMA } & \text { Homeostasis model assessment of insulin resistance index } \\ \text { LDL-C } & \text { Low-density lipoprotein cholesterol } \\ \text { NADH } & \text { Reduced nicotinamide adenine dinucleotide } \\ \text { RAA } & \text { Renin-angiotensin-aldosterone system } \\ \text { TC } & \text { Total cholesterol } \\ \text { TNF } & \text { Tumor necrosis factor } \\ \text { VCAM } & \text { Vascular cell adhesion molecule } \\ \text { VLDL-C } & \text { Very low-density lipoprotein cholesterol }\end{array}$

\section{References}

1. Singh, S.K.; Rahman, A.; Dixit, K.; Nath, A.; Sundaram, S. Evaluation of promising algal strains for sustainable exploitation coupled with $\mathrm{CO}_{2}$ fixation. Environ. Technol. 2016, 37, 613-622. [CrossRef] [PubMed]

2. Mühling, M.; Belay, A.; Whitton, B.A. Variation in fatty acid composition of Arthrospira (Spirulina) strains. J. Appl. Phycol. 2005, 17, 137-146. [CrossRef]

3. Deng, R.; Chow, T.-J. Hypolipidemic, Antioxidant, and Antiinflammatory Activities of Microalgae Spirulina. Cardiovasc. Ther. 2010, 28, e33-e45. [CrossRef] [PubMed]

4. Siva Kiran, R.; Madhu, G.; Satyanarayana, S. Spirulina in combating protein energy malnutrition (PEM) and protein energy wasting (PEW)-A review. J. Nutr. Res. 2015, 3, 62-79.

5. Holman, B.W.B.; Malau-Aduli, A.E.O. Spirulina as a livestock supplement and animal feed. J. Anim. Physiol. Animal Nutr. 2013, 97, 615-623. [CrossRef]

6. Zahroojian, N.; Moravej, H.; Shivazad, M. Effects of dietary marine algae (Spirulina platensis) on egg quality and production performance of laying hens. J. Agric. Sci. Technol. 2013, 15, 1353-1360.

7. Kalafati, M.; Jamurtas, A.Z.; Nikolaidis, M.G.; Paschalis, V.; Theodorou, A.A.; Sakellariou, G.K.; Koutedakis, Y.; Kouretas, D. Ergogenic and antioxidant effects of spirulina supplementation in humans. J. Med. Sci. Sports Exerc. 2010, 42, 142-151. [CrossRef]

8. Ovando, C.A.; Carvalho, J.C.d.; Vinícius de Melo Pereira, G.; Jacques, P.; Soccol, V.T.; Soccol, C.R. Functional properties and health benefits of bioactive peptides derived from Spirulina: A review. Food Rev. Int. 2018, 34, 34-51. [CrossRef]

9. Machu, L.; Misurcova, L.; Vavra Ambrozova, J.; Orsavova, J.; Mlcek, J.; Sochor, J.; Jurikova, T. Phenolic content and antioxidant capacity in algal food products. Molecules 2015, 20, 1118-1133. [CrossRef]

10. Rahman, N.; Riaz, M.; Khan, A.; Dima, L. Mechanism of Anti-Inflammatory and Anti-Nociceptive Actions of Acacia modesta in Animal Models. Pak. J. Zool. 2015, 47, 1723-1730.

11. O'Neill, S.; O'Driscoll, L. Metabolic syndrome: A closer look at the growing epidemic and its associated pathologies. Etiol. Pathophysiol. 2015, 16, 1-12. [CrossRef] [PubMed]

12. Kaur, J. A Comprehensive Review on Metabolic Syndrome. Cardiol. Res. Practice. 2014, $2014,943162$. [CrossRef] [PubMed]

13. Greendale, G.A.; Lee, N.P.; Arriola, E.R. The menopause. Lancet 1999, 353, 571-580. [CrossRef]

14. Dima, L.; Bălan, A.; Moga, M.A.; Dinu, C.G.; Dimienescu, O.G.; Varga, I.; Neculau, A.E. Botulinum Toxin a Valuable Prophylactic Agent for Migraines and a Possible Future Option for the Prevention of Hormonal Variations-Triggered Migraines. Toxins 2019, 11, 465. [CrossRef] [PubMed]

15. Moga, M.; Preda, G.; Marceanu, L.; Miclaus, R.; Bagiu, N. Lifestyle factors related to bone mineral density in postmenopausal women. J. Environ. Protect Ecol. 2008, 9, 67-69. 
16. Bobescu, E.; Rus, H.; Strempel, C. The drugs with effect in reduction of oxidative stress, platelets aggregation and pro-coagulant status in patients with acute coronary syndromes and diabetes mellitus. In Proceedings of the INTERDIAB 2016: Diabetes Mellitus as Cardiovascular Disease, Bucharest, Romania, 3-5 March 2006; Book Series: International Conference on Interdisciplinary Management of Diabetes Mellitus and Its Complications. pp. 109-116.

17. Jouyandeh, Z.; Nayebzadeh, F.; Qorbani, M.; Asadi, M. Metabolic syndrome and menopause. J. Diabetes Metab. Dis. 2013, 12, 1. [CrossRef]

18. Bălan, A.; Moga, M.A.; Dima, L.; Toma, S.; Elena Neculau, A.; Anastasiu, C.V. Royal Jelly-A Traditional and Natural Remedy for Postmenopausal Symptoms and Aging-Related Pathologies. Molecules 2020, 25, 3291. [CrossRef]

19. Kumari, D.J.; Babitha, B.; Jaffar, S.; Prasad, M.G.; Ibrahim, M.; Khan, M. Potential health benefits of Spirulina platensis. Int. J. Adv. Pharm. Sci. 2011, 2, 417-422.

20. Eshtiaghi, R.; Esteghamati, A.; Nakhjavani, M. Menopause is an independent predictor of metabolic syndrome in Iranian women. Maturitas 2010, 65, 262-266. [CrossRef]

21. Heitmann, B.L.; Westerterp, K.R.; Loos, R.J.F.; Sørensen, T.I.A.; O’Dea, K.; McLean, P.; Jensen, T.K.; Eisenmann, J.; Speakman, J.R.; Simpson, S.J.; et al. Obesity: Lessons from evolution and the environment. Obes. Rev. 2012, 13, 910-922. [CrossRef]

22. Clegg, D.J. Minireview: The Year in Review of Estrogen Regulation of Metabolism. Mol. Endocrinol. 2012, 26, 1957-1960. [CrossRef] [PubMed]

23. Carr, M.C. The Emergence of the Metabolic Syndrome with Menopause. J. Clin. Endocrinol. Metab. 2003, 88, 2404-2411. [CrossRef] [PubMed]

24. Poehlman, E.T.; Toth, M.J.; Gardner, A.W. Changes in Energy Balance and Body Composition at Menopause: A Controlled Longitudinal Study. Brief Comm. 1995, 123, 673-675. [CrossRef]

25. Harwood, H.J. The adipocyte as an endocrine organ in the regulation of metabolic homeostasis. Neuropharmacology 2012, 63, 57-75. [CrossRef]

26. Miller, W.L.; Auchus, R.J. The Molecular Biology, Biochemistry, and Physiology of Human Steroidogenesis and Its Disorders. Endocr. Rev. 2011, 32, 81-151. [CrossRef]

27. Rodriguez-Cuenca, S.; Monjo, M.; Frontera, M.; Gianotti, M.; Proenza, A.M.; Roca, P. Sex Steroid Receptor Expression Profile in Brown Adipose Tissue. Effects of Hormonal Status. Cell Physiol. Biochem. 2007, 20, 877-886. [CrossRef]

28. Park, C.J.; Zhao, Z.; Glidewell-Kenney, C.; Lazic, M.; Chambon, P.; Krust, A.; Weiss, J.; Clegg, D.J.; Dunaif, A.; Jameson, J.L.; et al. Genetic rescue of nonclassical ER $\alpha$ signaling normalizes energy balance in obese Er $\alpha$-null mutant mice. J. Clin. Investig. 2011, 121, 604-612. [CrossRef]

29. Austin, M.A.; King, M.C.; Vranizan, K.M.; Newman, B.; Krauss, R.M. Inheritance of low-density lipoprotein subclass patterns: Results of complex segregation analysis. Am. J. Hum. Genet. 1988, 43, 838-846.

30. Campos, H.; McNamara, J.R.; Wilson, P.W.; Ordovas, J.M.; Schaefer, E.J. Differences in low density lipoprotein subfractions and apolipoproteins in premenopausal and postmenopausal women. J. Clin. Endocrinol. Metab. 1988, 67, 30-35. [CrossRef]

31. Poehlman, E.T.; Toth, M.J.; Ades, P.A.; Rosen, C.J. Menopause-associated changes in plasma lipids, insulin-like growth factor I and blood pressure: A longitudinal study. Eur. J. Clin. Investig. 1997, 27, 322-326. [CrossRef]

32. Carr, M.C.; Kim, K.H.; Zambon, A.; Mitchell, E.S.; Woods, N.F.; Casazza, C.P.; Purnell, J.Q.; Hokanson, J.E.; Brunzell, J.D.; Schwartz, R.S. Changes in LDL density across the menopausal transition. J. Investig. Med. 2000, 48, 245-250. [PubMed]

33. Wassertheil-Smoller, S.; Anderson, G.; Psaty, B.M.; Black, H.R.; Manson, J.; Wong, N.; Francis, J.; Grimm, R.; Kotchen, T.; Langer, R.; et al. Hypertension and its treatment in postmenopausal women. Hypertension 2000, 36, 780-789. [CrossRef] [PubMed]

34. Maas, A.H.E.M.; Franke, H.R. Women's health in menopause with a focus on hypertension. Netherlands Heart J. 2009, 17, 68-72. [CrossRef]

35. Reckelhoff, J.F.; Fortepiani, A. Novel mechanisms responsible for postmenopausal hypertension. Hypertension 2004, 43, 918-923. [CrossRef] [PubMed]

36. Thorndike, E.; Turner, A. In search of an animal model for postmenopausal diseases. Front. Biosci. 1998, 3, 17-26. [CrossRef] [PubMed] 
37. Gupte, A.A.; Pownall, H.J.; Hamilton, D.J. Estrogen: An Emerging Regulator of Insulin Action and Mitochondrial Function. J. Diabetes Res. 2015, 2015, 916585. [CrossRef] [PubMed]

38. Barros, R.P.A.; Gabbi, C.; Morani, A.; Warner, M.; Gustafsson, J.-Å. Participation of ER $\alpha$ and ER $\beta$ in glucose homeostasis in skeletal muscle and white adipose tissue. Endocrinol. Metab. 2009, 297, E124-E133. [CrossRef]

39. Carey, V.J.; Walters, E.E.; Colditz, G.A.; Solomon, C.G.; Willett, W.C.; Rosner, B.A.; Speizer, F.E.; Manson, J.E. Body fat distribution and risk of non-insulin-dependent diabetes mellitus in women. The Nurses' Health Study. Am. J. Epidemiol. 1997, 145, 614-619. [CrossRef]

40. Stumvoll, M.; Goldstein, B.J.; van Haeften, T.W. Type 2 diabetes: Principles of pathogenesis and therapy. Lancet 2005, 365, 1333-1346. [CrossRef]

41. Polotsky, H.N.; Polotsky, A.J. Metabolic Implications of Menopause. Semin. Reprod. Med. 2010, $28,426-434$. [CrossRef]

42. Lafarga, T.; Fernández-Sevilla, J.M.; González-López, C.; Acién-Fernández, F.G. Spirulina for the food and functional food industries. Food Res. Int. 2020, 137, 109356. [CrossRef] [PubMed]

43. Dean, A.P.; Estrada, B.; Nicholson, J.M.; Sigee, D.C. Molecular response of Anabaena flos-aquae to differing concentrations of phosphorus: A combined Fourier transform infrared and X-ray microanalytical study. Phycol. Res. 2008, 56, 193-201. [CrossRef]

44. Garrido-Cardenas, J.A.; Manzano-Agugliaro, F.; Acien-Fernandez, F.G.; Molina-Grima, E. Microalgae research worldwide. Algal. Res. 2018, 35, 50-60. [CrossRef]

45. Parsons, T.R.; Stephens, K.; Strickland, J.D.H. On the Chemical Composition of Eleven Species of Marine Phytoplankters. J. Fish Res. Board Canada 1961, 18, 1001-1016. [CrossRef]

46. Finkel, Z.V.; Follows, M.J.; Liefer, J.D.; Brown, C.M.; Benner, I.; Irwin, A.J. Phylogenetic diversity in the macromolecular composition of microalgae. PLoS ONE 2016, 11, e0155977. [CrossRef] [PubMed]

47. Tedesco, M.A.; Duerr, E.O. Light, temperature and nitrogen starvation effects on the total lipid and fatty acid content and composition of Spirulina platensis UTEX 1928. J. Appl. Phycol. 1989, 1, 201-209. [CrossRef]

48. Markou, G. Alteration of the biomass composition of Arthrospira (Spirulina) platensis under various amounts of limited phosphorus. Biores. Technol. 2012, 116, 533-535. [CrossRef]

49. Ljubic, A.; Safafar, H.; Holdt, S.L.; Jacobsen, C. Biomass composition of Arthrospira platensis during cultivation on industrial process water and harvesting. J. App. Phycol. 2018, 30, 943-954. [CrossRef]

50. Morist, A.; Montesinos, J.L.; Cusidó, J.A.; Gòdia, F. Recovery and treatment of Spirulina platensis cells cultured in a continuous photobioreactor to be used as food. Process Biochem. 2001, 37, 535-547. [CrossRef]

51. Wang, Y.; Ocampo, M.; Rodriguez, B.; Chen, J. Resveratrol and Spirulina: Nutraceuticals that Potentially Improving Cardiovascular Disease. J. Cardiovasc. Med. Cardiol. 2020, 7, 138-145. [CrossRef]

52. Liwa, A.C.; Barton, E.N.; Cole, W.C.; Nwokocha, C.R. Bioactive Plant Molecules, Sources and Mechanism of Action in the Treatment of Cardiovascular Disease. In Pharmacognosy; Academic Press: Boston, MA, USA, 2017; pp. 315-336. [CrossRef]

53. Carcea, M.; Sorto, M.; Batello, C.; Narducci, V.; Aguzzi, A.; Azzini, E.; Fantauzzi, P.; Finotti, E.; Gabrielli, P.; Galli, V.; et al. Nutritional characterization of traditional and improved dihé, alimentary blue-green algae from the lake Chad region in Africa. Food Sci. Technol. 2015, 62, 753-763. [CrossRef]

54. Watanabe, F.; Yabuta, Y.; Tanioka, Y.; Bito, T. Biologically Active Vitamin B12 Compounds in Foods for Preventing Deficiency among Vegetarians and Elderly Subjects. J. Agric. Food Chem. 2013, 61, 6769-6775. [CrossRef] [PubMed]

55. Rangel-Yagui, C.d.O.; Danesi, E.D.G.; de Carvalho, J.C.M.; Sato, S. Chlorophyll production from Spirulina platensis: Cultivation with urea addition by fed-batch process. Biores. Technol. 2004, 92, 133-141. [CrossRef] [PubMed]

56. Queiroz Zepka, L.; Jacob-Lopes, E.; Roca, M. Catabolism and bioactive properties of chlorophylls. Curr. Opin. Food Sci. 2019, 26, 94-100. [CrossRef]

57. Morais, M.G.d.; Vaz, B.d.S.; Morais, E.G.d.; Costa, J.A.V. Biological Effects of Spirulina (Arthrospira) Biopolymers and Biomass in the Development of Nanostructured Scaffolds. Biomed. Res. Int. 2014, 2014, 762705. [CrossRef]

58. Moradi, S.; Ziaei, R.; Foshati, S.; Mohammadi, H.; Nachvak, S.M.; Rouhani, M.H. Effects of Spirulina supplementation on obesity: A systematic review and meta-analysis of randomized clinical trials. Complement. Ther. Med. 2019, 47, 102211. [CrossRef] 
59. Fujimoto, M.; Tsuneyama, K.; Fujimoto, T.; Selmi, C.; Gershwin, M.E.; Shimada, Y. Spirulina improves non-alcoholic steatohepatitis, visceral fat macrophage aggregation, and serum leptin in a mouse model of metabolic syndrome. Dig. Liver Dis. 2012, 44, 767-774. [CrossRef]

60. Mazokopakis, E.E.; Papadomanolaki, M.G.; Fousteris, A.A.; Kotsiris, D.A.; Lampadakis, I.M.; Ganotakis, E.S. The hepatoprotective and hypolipidemic effects of Spirulina (Arthrospira platensis) supplementation in a Cretan population with non-alcoholic fatty liver disease: A prospective pilot study. Ann. Gatroenterol. 2014, 27, 387-394.

61. Hassan, H.A.; El-Gharib, N.E. Obesity and Clinical Riskiness Relationship: Therapeutic Management by Dietary Antioxidant Supplementation-A Review. Appl. Biochem. Biotechnol. 2015, 176, 647-669. [CrossRef]

62. Hernández-Lepe, M.A.; López-Díaz, J.A.; Juárez-Oropeza, M.A.; Hernández-Torres, R.P.; Wall-Medrano, A.; Ramos-Jiménez, A. Effect of Arthrospira (Spirulina) maxima supplementation and a systematic physical exercise program on the body composition and cardiorespiratory fitness of overweight or obese subjects: A double-blind, randomized, and crossover controlled trial. Mar. Drugs 2018, 16, 364. [CrossRef]

63. Szulinska, M.; Gibas-Dorna, M.; Miller-Kasprzak, E.; Suliburska, J.; Miczke, A.; Walczak-Gałezewska, M.; Stelmach-Mardas, M.; Walkowiak, J.; Bogdanski, P. Spirulina maxima improves insulin sensitivity, lipid profile, and total antioxidant status in obese patients with well-treated hypertension: A randomized double-blind placebo-controlled study. Eur. Rev. Med. Pharmacol. Sci. 2017, 21, 2473-2481. [PubMed]

64. Ramamoorthy, A.; Premakumari, S. Effect of supplementation of Spirulina on hypercholesterolemic patients. J. Food Sci. Technol. 1996, 33, 124-127.

65. Miczke, A.; Szulińska, M.; Hansdorfer-Korzon, R.; Kręgielska-Narożna, M.; Suliburska, J.; Walkowiak, J.; Bogdański, P. Effects of spirulina consumption on body weight, blood pressure, and endothelial function in overweight hypertensive Caucasians: A double-blind, placebo-controlled, randomized trial. Eur. Rev. Med. Pharmacol. Sci. 2016, 20, 150-156. [PubMed]

66. Zeinalian, R.; Farhangi, M.A.; Shariat, A.; Saghafi-Asl, M. The effects of Spirulina Platensis on anthropometric indices, appetite, lipid profile and serum vascular endothelial growth factor (VEGF) in obese individuals: A randomized double blinded placebo controlled trial. BMC Complement. Alternat. Med. 2017, 17, 225. [CrossRef]

67. Yousefi, R.; Saidpour, A.; Mottaghi, A. The effects of Spirulina supplementation on metabolic syndrome components, its liver manifestation and related inflammatory markers: A systematic review. Complement. Ther. Med. 2019, 42, 137-144. [CrossRef]

68. Han, L.-K.; Li, D.-X.; Xiang, L.; Gong, X.-J.; Kondo, Y.; Suzuki, I.; Okuda, H. Isolation of pancreatic lipase activity-inhibitory component of spirulina platensis and it reduce postprandial triacylglycerolemia. J. Pharm. Soc. Jpn. 2006, 126, 43-49. [CrossRef]

69. Cheong, S.H.; Kim, M.Y.; Sok, D.-E.; Hwang, S.-Y.; Kim, J.H.; Kim, H.R.; Lee, J.H.; Kim, Y.-B.; Kim, M.R. Spirulina Prevents Atherosclerosis by Reducing Hypercholesterolemia in Rabbits Fed a High-Cholesterol Diet. J. Nutr. Sci. Vitaminol. 2010, 56, 34-40. [CrossRef]

70. Siah, K.C.; Yue, Y.; Youngki, P.; Jiyoung, L. Health Benefits of Blue-Green Algae: Prevention of Cardiovascular Disease and Nonalcoholic Fatty Liver Disease. J. Med. Food 2013, 16, 103-111. [CrossRef]

71. Torres-Duran, P.V.; Ferreira-Hermosillo, A.; Juarez-Oropeza, M.A. Antihyperlipemic and antihypertensive effects of Spirulina maxima in an open sample of mexican population: A preliminary report. Lipids Health Dis. 2007, 6, 33. [CrossRef]

72. Kim, W.Y.; Park, J.Y.J. The Effect of Spirulina on Lipid Metabolism, Antioxidant Gapacity and Immune Function in Korean Elderlies. Korean J. Nutr. 2003, 36, 287-297.

73. Zhang, L.; Bao, L.; Li, Y.; Wang, C.; Dong, X.; Abdulai, T.; Yang, X.; Fan, M.; Cui, S.; Zhou, W.; et al. Age at menopause, body mass index, and risk of type 2 diabetes mellitus in postmenopausal Chinese women: The Henan Rural Cohort study. Nutr. Metab. Cardiovasc. Dis. 2020, 30, 1347-1354. [CrossRef] [PubMed]

74. Bitam, A.; Aissaoui, O. Spirulina platensis, oxidative stress, and diabetes. In Diabetes, 2nd ed.; Preedy, V.R., Ed.; Academic Press: Cambridge, MA, USA, 2020; pp. 325-331. [CrossRef]

75. Hu, S.; Fan, X.; Qi, P.; Zhang, X. Identification of anti-diabetes peptides from Spirulina platensis. J. Funct. Foods 2019, 56, 333-341. [CrossRef]

76. Panam, P.; Uliyar, M.; Uma, I. Role of Spirulina in the Control of Glycemia and Lipidemia in Type 2 Diabetes Mellitus. J. Med. Food 2001, 4, 193-199. [CrossRef] 
77. Park, H.J.; Lee, Y.J.; Ryu, H.K.; Kim, M.H.; Chung, H.W.; Kim, W.Y. A Randomized Double-Blind, Placebo-Controlled Study to Establish the Effects of Spirulina in Elderly Koreans. Ann. Nutr. Metab. 2008, 52, 322-328. [CrossRef]

78. Mani, U.V.; Desai, S.; Iyer, U. Studies on the Long-Term Effect of Spirulina Supplementation on Serum Lipid Profile and Glycated Proteins in NIDDM Patients. J. Nutr. Funct. Med. Foods 2000, 2, 25-32. [CrossRef]

79. Anitha, L.; Chandralekha, K. Effect of supplementation of Spirulina on blood glucose, glycosylated hemoglobin and lipid profile of male non-insulin dependent diabetics. Asian J. Exp. Biol. Sci. 2010, 1, $36-46$.

80. Azabji-Kenfack, M.; Ekali, L.G.; Sobngwi, E.; Arnold, O.E.; Sandrine, E.D.; Von der Weid, D.; Gbaguidi, E.; Ngogang, J.; Mbanya, J.C. The effect of Spirulina platensis versus soybean on insulin resistance in HIV-infected patients: A randomized pilot study. Nutrients 2011, 3, 712-724. [CrossRef]

81. Soheili, M.; Khosravi-Darani, K. The Potential Health Benefits of Algae and Micro Algae in Medicine: A Review on Spirulina platensis. Curr. Nutr. Food Sci. 2011, 7, 279-285. [CrossRef]

82. Suetsuna, K.; Chen, J.-R. Identification of Antihypertensive Peptides from Peptic Digest of Two Microalgae, Chlorella vulgaris and Spirulina platensis. Mar. Biotechnol. 2001, 3, 305-309. [CrossRef]

83. Martínez-Sámano, J.; Torres-Montes de Oca, A.; Luqueño-Bocardo, O.I.; Torres-Durán, P.V.; Juárez-Oropeza, M.A. Spirulina maxima Decreases Endothelial Damage and Oxidative Stress Indicators in Patients with Systemic Arterial Hypertension: Results from Exploratory Controlled Clinical Trial. Mar. Drugs 2018, 16, 496. [CrossRef]

84. Lee, E.H.; Park, J.-E.; Choi, Y.-J.; Huh, K.-B.; Kim, W.-Y. A randomized study to establish the effects of spirulina in type 2 diabetes mellitus patients. Nutr. Res. Pract. 2008, 2, 295-300. [CrossRef] [PubMed]

85. Samuels, R.; Mani, U.V.; Nayak, U.S. Hypocholesterolemic Effect of Spirulina in Patients with Hyperlipidemic Nephrotic Syndrome. J. Med. Food 2002, 5, 91-96. [CrossRef] [PubMed]

86. Kaur, K.; Sachdeva, R.; Grover, K. Effect of supplementation of Spirulina on blood glucose and lipid profile of the non-insulin dependent diabetic male subjects. J. Dairy Foods Home Sci. 2008, 27, 202-208.

87. Ismail, M.; Hossain, M.F.; Tanu, A.R.; Shekhar, H.U. Effect of Spirulina Intervention on Oxidative Stress, Antioxidant Status, and Lipid Profile in Chronic Obstructive Pulmonary Disease Patients. Biomed. Res. Int. 2015, 2015, 486120. [CrossRef]

88. Ngo-Matip, M.-E.; Pieme, C.A.; Azabji-Kenfack, M.; Biapa, P.C.N.; Germaine, N.; Heike, E.; Moukette, B.M.; Emmanuel, K.; Philippe, S.; Mbofung, C.M.; et al. Effects of Spirulina platensis supplementation on lipid profile in HIV-infected antiretroviral naïve patients in Yaounde-Cameroon: A randomized trial study. Lipids Health Dis. 2014, 13, 191. [CrossRef]

89. Park, H.-J.; Lee, H.-S. The influence of obesity on the effects of spirulina supplementation in the human metabolic response of Korean elderly. Nutr. Res. Pract. 2016, 10, 418-423. [CrossRef]

90. Pancholi, D.; Qureshi, I. Nutritional Influence (Spirulina) of Biochemical and Obese Stress Patients. J. Biol. Chem. Chron. 2019, 5, 11-13. [CrossRef]

91. Handoo, S. 9 Shocking Side Effects of Spirulina. 2020. Available online: https://www.stylecraze.com/articles/ dangerous-side-effects-of-spirulina (accessed on 15 October 2020).

92. Wong, C. The Health Benefits of Spirulina. Holistic Health 2020. Available online: https://www.verywellhealth. com/the-benefits-of-spirulina-89079 (accessed on 15 October 2020).

93. Lee, A.N.; Werth, V.P. Activation of autoimmunity following use of immunostimulatory herbal supplements. Arch. Dermatol. 2004, 140, 723-727. [CrossRef]

94. Mazokopakis, E.E.; Karefilakis, C.M.; Tsartsalis, A.N.; Milkas, A.N.; Ganotakis, E.S. Acute rhabdomyolysis caused by Spirulina (Arthrospira platensis). Phytomedicine 2008, 15, 525-527. [CrossRef]

95. Le, T.-M.; Knulst, A.C.; Röckmann, H. Anaphylaxis to Spirulina confirmed by skin prick test with ingredients of Spirulina tablets. Food Chem. Toxicol. 2014, 74, 309-310. [CrossRef]

96. Sotiroudis, T.G.; Sotiroudis, G.T. Health aspects of Spirulina (Arthrospira) microalga food supplement. J. Serb. Chem. Soc. 2013, 78, 395-405. [CrossRef]

Publisher's Note: MDPI stays neutral with regard to jurisdictional claims in published maps and institutional affiliations. 